\title{
ANALISIS FAKTOR YANG BERHUBUNGAN DENGAN KEAKTIFAN POSYANDU PADA ERA COVID-19 DI DESA PEMATANG PELINTAHAN
}

Analysis of Factors Related to POSYANDU Activity in the Covid-19 Era in Pematang Pelintahan Village

\section{NURHAMIDA FITHRI}

STIKes SENIOR MEDAN

JL. Jamin Ginting KM.8,5 No.13, Mangga, Kec. Medan Tuntungan, Kota Medan, Sumatera Utara e-mail:pitipitinez@gmail.com

DOI: $10.35451 / j k k . v 4 i 1.795$

\begin{abstract}
During the Covid-19 pandemic, the social conditions of the community connected with health services for infants and toddlers, including posyandu activities. The routine implementation of the posyandu is neglected, including monitoring the growth and development of infants and toddlers and immunization coverage. This is because all services and health are focused on Covid-19. The initial survey conducted in Pelintahan Village, there were 9 posyandu and there was a decline in the implementation of the posyandu program during the Covid-19 pandemic. In addition, the report on immunization coverage also appears to be decreasing. To analyze the factors that relate to the activity of posyandu in the Covid-19 era in Pelintahan Village in 2021. This study used an analytical research design using a cross sectional approach. The population in this study were all mothers who have toddlers in Pelintahan Village as many as 59 people. The sample size in this study used the accidental sampling technique. The sample was taken when posyandu activities in Pelintahan Village took place during the time the research took place and amounted to 36 people. Data analysis in this study used the chi-square statistical test. The results of the study found that there was a significant relationship between maternal anxiety and family support for posyandu activities in the Covid-19 era in Pelintahan Village in 2021 with each $p$-value of 0.00 ( $p$-value $<0.05$ ). From the results of this study, it is expected that health workers can provide health education to mothers and families who have babies and toddlers providing health promotion, counseling and counseling related to safe posyandu during the Covid-19 pandemic.
\end{abstract}

Keywords: Anxiety, Family Support, Posyandu, The Covid-19 Pandemic

\section{PENDAhUluan}

World Health Organization (WHO) pada akhir tahun 2019 mengumumkan Covid-19 merupakan penyakit menular yang disebabkan Virus Corona (Virus SARS-COV 2) (Zhong et al., 2020).
Tertundanya pelayanan imunisasi merupakan salah satu dampak terbesar pandemi Covid-19 pada bidang pelayanan kesehatan ibu dan anak sehingga petugas serta kader kesehatan harus memprioritaskan 
anak-anak yang tercatat belum mendapatkan pelayanan imunisasi agar mendapat kesempatan pertama untuk di imunisasi.

Pada masa pandemi Covid-19 kondisi sosial masyarakat berhubungan dengan pelayanan kesehatan bayi dan balita termasuk diantaranya kegiatan posyandu. Rutinitas pelaksanaan posyandu terabaikan termasuk pemantauan tumbuh kembang bayi balita dan cakupan imunisasi. Hal tersebut dikarenakan seluruh pelayanan dan kesehatan terfokus pada Covid-19 (Juwita, 2020).

Pelayanan pencegahan dan penanganan kasus Covid-19 merupakan hal yang penting pada saat ini, namun kegiatan pelayanan pengawasan tumbuh kembang serta pemberian imunisasi pada anak juga merupakan hal yang sangat penting dan selayaknya menjadi prioritas untuk dilaksanakan karena hal tersebut termasuk pelayanan kesehatan unyuk pencegahan kasus covid-19 pada anak-anak. Hal tersebut dikarenakan pengawasan tumbuh kembang serta imunisasi dapat menjadi tolak ukur petugas kesehatan dalam menilai tingkat imunitas bayi dan balita pada tahap awal kehidupannya sebagai indikator derajat kesehatannya (Direktur Jenderal Pencegahan dan Pengendalian Penyakit Kemenkes RI, 2020).

Pemberian imunisasi serta pemantauan tumbuh kembang bayi balita pada pelaksanaan pelayanan posyandu sempat terhenti dikarenakan pandemi Covid-19 melanda dunia sehingga pelaksanaan pelayanan posyandu tergantung dari kebijaksanaan masing-masing daerah sesuai kondisi dan zona aman covid-19 daerahnya masing-masing (Sari \& Utami, 2020).

Dalam pelaksanaan kegiatan posyandu belum berjalan dengan baik, dikarenakan adanya kekhawatiran masyarakat membawa bayi dan balitanya ke tempat pelayanan kesehatan maupun posyandu karena takut akan tertular virus Covid-19. Selain kekhawatiran dari masyarakat, pelayanan kesehatan posyandu tidak dapat bergerak ke daerah-daerah wilayah kerjanya karena pembatasan kegiatan serta pembatasan akses jalan sehingga tidak terpenuhinya taget dalam pemberian imunisasi (Direktur Jenderal Pencegahan dan Pengendalian Penyakit Kemenkes RI, 2020).

Dengan adanya pembatasan kegiatan di masa pandemi ini (New Normal) dengan pelaksanaan pelayanan posyandu oleh pemerintah harus sesuai dan mematuhi protokol kesehatan yang telah ditetapkan untuk mengecilkan angka kejadian kasus penularan virus Covid-19, maka kegiatan posyandu dibeberapa daerah sudah mulai aktif kembali (Sari \& Utami, 2020).

Pada posyandu, puskesmas dan fasilitas kesehatan lainnya yang biasanya memberikan layanan imunisasi, pelayanan imunisasi dapat tetap dilaksanakan sesuai jadwal dan prinsip PPI serta menjaga jarak aman 1 - 2 meter. Salah satu upaya untuk memenuhi pelayanan kesehatan posyandu maupun pelayanan kesehatan secara umum maka dilakukan pelayanan kesehatan mobile yang sifatnya bergerak keliling untuk menjangkau wilayah kerja puskesmas yang belum terjangkau karena pembatasan kegiatan di masa pandemi Covid-19 sehingga menepis rasa takut masyarakat akan penularan virus covid-19.

Acuan untuk melakukan pelayanan imunisasi di posyandu, puskesmas dan fasilitas kesehatan lainnya yang memberikan layanan 
imunisasi serta puskesmas keliling. Kemudahan akses ke sarana pelayanan kesehatan berhubungan dengan beberapa faktor penentu, antara lain jarak tempat tinggal dan waktu tempuh ke sarana kesehatan termasuk posyandu (Depekes RI, 2018). Jarak yang dimaksud disini adalah jauh dekatnya jarak dari rumah atau tempat tinggal ke tempat pelayanan kesehatan/ posyandu. Berdasarkan hasil penelitian Qiftiyah, (2018) di desa Tegalrejo menyatakan bahwa jarak mempunyai hubungan terhadap partisipasi ibu ke posyandu, ada tiga alasan rumah tangga (RT) tidak memanfaatkan pelayanan psoyandu yaitu layanan tidak lengkap, letak jauh dan tidak ada posyandu dan persentase terbanyak adalah pada alasan pelayanan tidak lengkap $(43,6 \%)$.

Survey awal yang dilakukan di Desa Pematang Pelintahan Sei Rampah, terdapat 4 posyandu dan terjadi penurunan pelaksanaan program posyandu selama masa pandemi Covid19. Selain itu dari laporan cakupan imunisasi juga tanpak penurunan yang cukup besar sebanyak $25 \%$ jika dibandingkan cakupan imunisasi di akhir tahun 2019. Hasil wawancara awal yang dilakukan kepada ibu yang memiliki bayi menyatakan bahwa banyak orangtua dan keluarga takut untuk membawa bayi dan balitanya ke posyandu ataupun ke puskesmas untuk imunisasi ataupun sekedar melakukan pemantauan tumbuh kembang bayinya. Kecemasan tersebut muncul dikarenakan tempat pelaksanaan posyandu yang belum mengikuti protokol kesehatan yang ada, dan rasa ketakutan yang muncul ketika berhadapan dengan petugas kesehatan.

\section{METODE}

Metode penelitian yang digunakan adalah penelitian analitik menggunakan pendekatan Cross Sectional. Penelitian ini bertujuan untuk menganalisis faktor yang berhubungan dengan Keaktifan Posyandu Pada Era Covid-19 Di Desa Pelintahan. Besar sampel pada penelitian ini sebanyak 39 orang ibu yang memiliki bayi 0-12 bulan dengan menggunakan teknik accidental sampling. Waktu penelitian berlangsung 4 minggu pada bulan April 2021. Instrumen penelitian ini menggunakan data primer yang diperoleh langsung dari subjek penelitian. Penelitian ini dilakukan masih dalam masa pandemi Covid-19 sehingga alat tulis diberikan 1 per responden penelitian dalam mengisi kuesioner tersebut untuk mencegah terjadinya penularan Covid-19. Sumber data dalam penelitian ini adalah data primer yang diperoleh dari wawancara dengan menggunakan angket/ lembar kusioner yang diberikan langsung kepada responden saat penelitian. Analisa data pada penelitian ini menggunakan analisa bivariat melalui uji statistik Chi Square.

\section{HASIL}

Tabel 1. Distribusi Frekuensi Faktor yang Berhubungan dengan Keaktifan Posyandu pada Era Covid-19 di Desa Pelintahan

\begin{tabular}{lcc}
\hline \multicolumn{1}{c}{ Faktor } & $\mathbf{f}$ & $\mathbf{\%}$ \\
\hline Kecemasan & & \\
Tidak cemas & 7 & 18.0 \\
Cemas ringan & 22 & 56.0 \\
Cemas sedang & 10 & 26.0 \\
Cemas berat & 0 & 0 \\
Panik & 0 & 0 \\
\hline Total & 39 & $100 \%$ \\
\hline Dukungan Keluarga & & \\
Rendah & 26 & 67.0 \\
Sedang & 10 & 25.6 \\
Tinggi & 3 & 7.7 \\
\hline Total & 39 & $100 \%$ \\
\hline Keaktifan Posyandu & & \\
Kurang aktif & 26 & 67.0 \\
Aktif & 13 & 33.0 \\
\hline
\end{tabular}




\begin{tabular}{llr}
\hline Total & 39 & $100 \%$ \\
\hline Berdasarkan & tabel & 1.
\end{tabular}

menunjukkan mayoritas responden berada ditingkat cemas, hanya 7 responden yang tidak cemas, 22 responden menunjukkan gejala cemas ringan dan terdapat 10 responden berada di tingkat cemas sedang. Selain itu, dari hasil penelitian ditemukan mayoritas responden mendapat dukungan yang rendah (67\%) ke pelayanan posyandu di era pandemi Covid-19, dan hanya $7.7 \%$ yang mendapatkan dukungan yang tinggi dari keluarga. Pada tabel di atas juga menunjukkan 26 responden (69\%) kurang aktif melakukan kunjungan ke posyandu di era pandemi Covid-19 ini dan hanya 13 responden (33\%) yang aktif melakukan kunjungan responden.

Tabel 2. Tabulasi Silang Hubungan Kecemasan Ibu Balita Dan Dukungan Keluarga Terhadap Keaktifan Posyandu Pada Era Covid-19 Di Desa Pelintahan Tahun 2021

\begin{tabular}{|c|c|c|c|c|c|c|}
\hline \multirow[t]{3}{*}{ Faktor } & \multicolumn{4}{|c|}{$\begin{array}{c}\text { Keaktifan Posyandu } \\
\text { di Era Covid-19 }\end{array}$} & \multirow{3}{*}{ Total } & $p-$ \\
\hline & \multicolumn{2}{|c|}{$\begin{array}{l}\text { Kurang } \\
\text { Aktif }\end{array}$} & \multicolumn{2}{|c|}{ Aktif } & & $\begin{array}{c}\text { I valu } \\
e\end{array}$ \\
\hline & $f$ & $\%$ & $f$ & $\%$ & & \\
\hline \multicolumn{7}{|l|}{ Kecemasan } \\
\hline Tidak cemas & 1 & 3.8 & 6 & 46.0 & 7 & \\
\hline Ringan & 15 & 57.7 & 7 & 54.0 & 22 & \\
\hline Sedang & 10 & 38.5 & 0 & 0 & 10 & 0.0 \\
\hline Berat & 0 & 0.0 & 0 & 0.0 & 0 & 00 \\
\hline Panik & 0 & 0.0 & 0 & 0.0 & 0 & \\
\hline Total & 26 & 100 & 13 & 100 & 39 & \\
\hline \multicolumn{7}{|l|}{$\begin{array}{l}\text { Dukungan } \\
\text { Keluarga }\end{array}$} \\
\hline Rendah & 24 & 92.0 & 2 & 15.0 & 26 & $\begin{array}{l}0.0 \\
00\end{array}$ \\
\hline Sedang & 2 & 8.0 & 8 & 62.0 & 10 & \\
\hline Tinggi & 0 & 0.0 & 3 & 23.0 & 3 & \\
\hline Total & 26 & 100 & 13 & 100 & 39 & \\
\hline
\end{tabular}

Dari tabel 2 diatas menunjukkan ada hubungan yang signifikan antara faktor kecemasan ibu balita terhadap keaktifan posyandu pada Era Covid-19 di Desa Pelintahan Tahun 2021 dengan $p$ value 0.00 ( $p$-value $<0.05$ ). Dalam penelitian ini dari 7 responden yang tidak cemas, 6 orang diantaranya aktif melakukan posyandu di era Covid-19 ini, hanya 1 orang saja yang tidak aktif. Responden yang memiliki rasa cemas sedang (10 orang) seluruhnya aktif melakukan kunjungan posyandu. Pada responden yang berada di cemas ringan, 15 responden (mayoritas) diantaranya kurang aktif melakukan kunjungan posyandu di era Covid-19.

Dari hasil penelitian yang telah dituangkan pada tabel tersebut juga diperoleh hasil ada hubungan dukungan keluarga terhadap keaktifan posyandu pada Era Covid19 di Desa Pelintahan Tahun 2021 dengan $p$-value $0.00 \quad$ ( $p$-value $<$ 0.05). responden yang memiliki dukungan keluarga yang rendah (24 responden), hanya 2 responden saja yang aktif melakukan kunjungan ke posyandu di era pandemi Covid-19. Seluruh repsonden yang mendapatkan dukungan keluarga yang tinggi seluruhnya didapati aktif melakukan kunjungan ke posyandu pada di era pandemi Covid-19.

\section{PEMBahasan}

Masalah yang muncul di tengah pandemi Covid-19 adalah rendahnya cakupan imunisasi dan pengukuran tumbuh kembang bayi balita yang disebabkan kurangnya keaktifan ibu dan keluarga membawa bayi-balitanya ke posyandu. Hasil penelitian ini sejalan dengan hasil penelitian sebelumnya (Aritonang, 2020) dimana hasil penelitian 
didapati bahwa mayoritas ibu mengalami kecemasan yang tinggi (78\%) pada saat membawa balitanya ke posyandu.

Kecemasan muncul dapat disebabkan adanya berbagai perubahan akibat Covid-19, masyarakat diharapkan dapat segera dapat beradaptasi di masa pandemi. Sering sekali hal tersebut memhubungani kondisi kesehatan masyarakat kerentanan secara fisiologis untuk tertular gejala Covid-19 (Rinaldi and Yuniasanti, 2020).

Menurut buku panduan pelayanan kesehatan balita di masa pandemi (Kemenkes, 2020) pelaksanaan posyandu wajib mematuhi protokol kesehatan sebagai berikut; 1) pelaksanaan pelayanan posyandu sudah disetujui oleh pemerintah setempat, 2) petugas kesehatan, kader dan anak, bayi balita serta orang tua atau pengasuh diharuskan dalam kondisi sehat dan tidak menunjukkan gejala demam, batuk, pilek. Hal tersebut dipastikan dengan cara menskrining suhu tubuh yang diperbolehkan $\leq 37,5^{\circ} \mathrm{C}$. Semua yang terlibat dalam pelaksanaan Posyandu menggunakan masker, 3) Memberitahukan informasi tersebut terlebih dahulu sehari sebelum hari pelayanan kepada masyarakat sasaran pelayanan, 4) diwajibkan memakai masker pada anak dan pengantar (minimal masker kain), 5) Pelayanan posyandu dilakukan di ruangan cukup luas agar terjadi sirkulasi udara keluar dan udara masuk yang bagus, 6) Area tempat pelayanan posyandu dipastikan harus bersih sebelum dan sesudah pelayanan berdasarkan prinsip pencegahan penularan infeksi, 7) Pada pintu masuk serta pada area pelayanan harus disediakan fasilitas CTPS, handsanitizer atau cairan desinfektan untuk petugas kesehatan, kader dan sasaran anak serta pengantar, 8) Mengatur jarak meja pelayanan. Penularan virus Covid-19 dari petugas kesehatan atau dari pengunjung yang lain pada pelayanan kesehatan dan posyandu merupakan kekhawatiran terbesar mereka untuk datang berkunjung membawa bayi dan balitanya ke Posyandu.

Kecemasan yang tinggi ini pula yang mengakibatkan rendahnya kunjungan ibu balita pada saat kegiatan posyandu. Berdasarkan hasil penelitian ini menunjukkan bahwa masyarakat masih belum beradaptasi pada kegiatan posyandu maupun pelayanan kesehatan di masa pandemi covid-19 sekarang ini, sehingga perlu dilakukan inovasi untuk menciptakan posyandu yang aman sesuai dengan petunjuk teknis, disamping itu disarankan untuk melakukan promosi kesehatan menggunakan pendekatan interpersonal di masyarakat untuk meningkatkan pengetahuan, sikap dan merubah perilaku masyarakat. Seperti hasil penelitian yang dilakukan (Aritonang, 2020) menunjukkan bahwa melalui penyuluhan kesehatan kepada ibu bayi balita agar meningkatkan cakupan Imunisasi Pentabio lanjutan, dengan kader, ibu PKK, dan petugas kesehatan.

Pada penelitian ini, pada faktor dukungan keluarga peneliti merasakan kesulitan dalam membandingkan hasil penelitiannya dengan penelitian yang lain dikarenakan masih minimnya dan belum ada penelitian yang sama. Tetapi peneliti akan berupaya membandingkannya dengan penelitian yang hampir sama sesuai dengan faktor dukungan keluarga.

Berdasarkan

Keputusan

Mentri Kesehatan Nomor 1529 tahun 2010 tentang Pedoman Umum Pengembangan Desa dan Keluarga Siaga Aktif bahwa salah satu kriteria untuk mencapai Desa dan Kelurahan yang siaga aktif adalah keaktifan 
posyandu. Maka Kementrian Kesehatan Republik Indonesia harus memiliki solusi agar tetap dilaksanakan posyandu dimasa pandemi Covid-19. Salah satu solusi dalam permasalahan ini yaitu adanya Petunjuk Teknis Posyandu rekomendasi Kementrian Republik Indonesia agar tetap berjalannya Posyandu dengan mematuhi protokol kesehatan.

Menyikapi hal tersebut maka Menteri Kesehatan mengeluarkan petunjuk teknis pelayanan imunisasi pada masa pandemi Covid-19 pada tanggal 24 Maret 2020 yang menjadi acuan bagi petugas kesehatan di lapangan, sehingga keraguraguan tenaga kesehatan dan masyarakat tidak menjadi alasan anak-anak tidak diimunisasi akibat tidak adanya pedoman dalam pelayanan imunisasi ditengah pandemi Covid-19. Berdasarkan analisis situasi epidemiologi penyebaran COVID19 , cakupan imunisasi rutin, dan situasi epidemiologi PD3I melaksanakan pemberian imunisasi pada masa pandemi COVID-19 sesuai kebijakan pemerintah daerah setempat. Petugas kesehatan diharapkan dapat memantau status imunisasi setiap sasaran yang ada di wilayah kerjanya. (Yurianto, 2020).

Dukungan dari keluarga sangat diperlukan pada tiap kegiatan pelayanan kesehatan terutama pada pelaksanaan posyandu. Hasil penelitian (Sriarumtias, 2020) menunjukkan bahwa ada hubungan antara dukungan keluarga dengan keaktifan posyandu di Puskesmas Tanawangko Kecamatan Tombariri. Hal ini menunjukkan ibu balita yang mendapatkan dukungan keluarga maka keaktifan kunjungan posyandu di Puskesmas Tanawangko Kecamatan Tombariri akan semakin baik. Dukungan keluarga pada penelitian ini berupa dukungan emosional yang meliputi mendukung kader untuk mengikuti kegiatan pelaksanaan posyandu, memberikan pujian selama mengikuti kegiatan posyandu, menanyakan kendala saat kegiatan posyandu, dan keluarga juga memperhatikan kesehatan kader.

Pada dukungan sarana dan prasarana berupa dukungan keluarga dalam membantu menyiapkan sarana dan prasarana yang dibutuhkan untuk kegiatan posyandu. Ibu juga mendapatkan dukungan informasi, yaitu keluarga membantu dalam memberikan nasehat dan juga mengingatkan jadwal kegiatan dari posyandu. Bertambahnya dukungan dari orangorang terdekat, misalnya keluarga, teman-teman sekerja, dapat berdampak pada meningkatnya kegiatan ibu di Posyandu sehingga Posyandu akan semakin aktif.

Hasil penelitian ini sejalan dengan hasil penelitian yang pernah dilakukan Qiftiyah, (2018) didapati ada hubungan dukungan mertua dengan kemauan ibu membawa anak untuk diimunisasi vaksin Pentabio ( $p$ value $<0.005$ ). Hasil penelitian ini juga sesuai dengan teori bahwa dukungan keluarga (suami, orang tua, mertua maupun saudara lainnya) kepada ibu untuk ikut serta secara aktif dalam kegiatan pelayanan kesehatan di Posyandu, termasuk imunisasi. Keluarga adalah sumber motivasi karena dalam hubungan keluarga terwujud rasa saling mempercayai. Dukungan keluarga yang tinggi akan menjadikan seseorang lebih optimis dalam menghadapi masalah kesehatan dan kehidupan dan lebih terampil dalam memenuhi kebutuhan psikologi (Diharja, et all.2020).

Menurut asumsi peneliti dukungan keluarga pada ibu dalam kunjugan posyandu pada masa pandemi Covid-19 ini adalah; keluarga terutama suami memberikan penguatan kepercayaan diri kepada ibu agar dapat membawa 
bayi-balita keposyandu tanpa tertular Covid-19 apabila mematuhi protokol kesehatan. Bersama dengan keluarga mengingatkan protokol kesehatan yang baik itu bagaimana. Selain itu kelurga juga turut andil dalam mempersiapkan bahan-bahan yang dibawa selama posyandu seperti masker bayi ibu dan bayi-balitanya, hand sanitaizer, kain untuk alas penimbanga bayi, dll. Selain itu mengingatkan ibu, setelah pulang dari posyandu agar mandi begitu juga dengan bayinya.

\section{KESIMPULAN}

Penelitian ini menunjukkan bahwa ada hubungan yang signifikan antara kecemasan ibu balita terhadap keaktifan posyandu pada era Covid-19 di Desa Pelintahan Tahun 2021 dengan $p$ value 0.00 ( $p$-value $<0.05$ ) dan ada hubungan yang signifikan antara dukungan keluarga terhadap keaktifan posyandu pada era Covid-19 di Desa Pelintahan dengan $p$-value 0.00 ( $p$ value $<0.05$ ), sehingga diharapkan bidan, petugas kesehatan dan kader di Desa Pelintahan dapat meningkatkan kualitas pelayanan dengan memberikan pendidikan kesehatan khususnya di masa pandemi Covid-19 dan memberikan pelayanan yang baik pada saat posyandu berdasarkan protokol kesehatan yang baik.

\section{DAFTAR PUSTAKA}

Aritonang, J, Nugreny, L,. (2020). Peningkatan Pemahaman Kesehatan pada Ibu Hamil dalam Upaya Pencegahan Covid-19. Jurnal Solma. http://dx.doi.org/10.22236/solma.v 9i2.5522

Diharja, N., et all., (2020). Pengaruh Pandemi Covid-19 Terhadap Kunjungan Imunisasi di Posyandu Desa Tanjungwangi. Asian Research Midwifery and Basic Science Journal. https://doi.org/10.37160/arimbi.v1i

\subsection{7}

Direktorat Promosi Kesehatan dan Pemberdayaan Masyarakat Kemenkes RI. (2019). Panduan Lokakarya Kader Posyandu. In Kementerian Kesehatan RI.

Direktur Jenderal Pencegahan dan Pengendalian Penyakit Kemenkes RI. (2020). Petunjuk Teknis Pelayanan Imunisasi Pada Masa Pandemi COVID-19. Kementerian Kesehatan Indonesia.

Juwita, D. R. (2020). Makna Posyandu Sebagai Sarana Pembelajaran Non Formal Di Masa Pandemic Covid 19. Meretas: Jurnal IImu Pendidikan.

Qiftiyah, M. (2018). Gambaran faktor status pekerjaan, pendidikan dan dukungan keluarga terhadap kunjungan posyandu balita usia 0-5 tahun di posyandu pepaya dukuh karangrejo desa tegalrejo kecamatan merakurak kabupaten tuban. Jurnal kebidanan. https://doi.org/10.30736/midpr o.v9i2.20

Rinaldi,M., Yuniasanti, R., (2020). Kecemasan pada Masyarakat Saat Masa Pandemi Covid-19 di Indonesia. Jurnal Covid-19 dalam Ragam Tinjauan Perspektif. https://scholar.google.co.id/citat ions?user $=$ Az5GgGoAAAAJ\&hI=i d

Saepuddin, E., Rizal, E., \& Rusmana, A. (2018). Posyandu Roles as Mothers and Child Health Information Center. Record and Library

Journal. 
https://doi.org/10.20473/rlj.v3-

i2.2017.201-208

Sari, R. P., \& Utami, U. (2020). Studi Analisis Tingkat Kecemasan Dengan Kepatuhan Kunjungan Posyandu Di Masa Pandemi Covid 19. Jurnal Ilmiah Maternal.

Sriarumtias, F. F., Andeani, R. F., Rosita, N., \& Ardian, F. (2020). Pemberdayaan serta Penerapan Protokol Kesehatan di Posyandu Puskesmas Leuwigoong Kabupaten Garut , Jawa Barat Sebagai Upaya Mencegah Penularan COVID-19. JURPIKAT (Jurnal Pengabdian Kepada Masyarakat).

Yurianto, Ahmad, Bambang Wibowo, K. P. (2020). Pedoman Pencegahan Dan Pengendalian Coronavirus Disease (Covid-19) (M. I. Listiana Azizah, Adistikah Aqmarina (ed.)

https://edukatif.org/index.php/edukatif/ index

Zhong, B. L., Luo, W., Li, H. M., Zhang, Q. Q., Liu, X. G., Li, W. T., \& Li, Y. (2020). Knowledge, attitudes, and practices towards COVID-19 among chinese residents during the rapid rise period of the COVID-19 outbreak: A quick online crosssectional survey. International Journal of Biological Sciences. https://doi.org/10.7150/ijbs.45221 